\title{
住宅の主室における室形状と室内要素の配列による空間構成 現代住宅作品の構成に関する研究

\author{
SPATIAL COMPOSITION BY FORM OF ROOM AND ARRANGEMENT \\ OF INTERIOR ELEMENTS IN CONTEMPORARY HOUSES
}

A study on spatial composition in contemporary houses

根本理恵*, 坂本一成**

Rie NEMOTO and Kazunari SAKAMOTO

\begin{abstract}
The aim of this paper is to clarify characteristics of interior space of contemporary Japanese houses in terms of their spatial composition with the relationship between the form of rooms and the arrangement of building elements. Form of rooms are analyzed in three levels of composition; the shape of the floor and ceiling, openness of the walls, and the height of the room. The arrangement of building elements are analyzed in two levels of composition; sorts of elements, and arrangement of these elements. Then 12 types of composition are found. Comparing the types, almost 4 characters are found, those are emphasis of shape of the room, synthesis of arrangement of elements, vertical articulation of interior space by relationship between shape of the room and arrangement of elements, and distributed arrangement of elements.
\end{abstract}

Keywords: contemporary house,Interior elements, Form, Arrangement, architectural composition

現代住宅, 室内要素, 形状, 配列, 構成形式

\section{1. 序}

\section{1 室形状と要素の配列による室内空間の意匠表現}

住宅は最も基本的かつ日常的なビルディングタイプであり、多く の建築家がその設計に関わり、社会的あるいは文化的な水準に関わ る意匠表現を成立させてきた。なかでも最も大きな室である主室 は生活の主要な場とされることが多く、そこに求められる機能は多 様かつ複合されたものであることから、実験的な構成形式の試みが 成される場として、また作品としての表現が集中寸る場として中心 的なものであると考えられる。

伝統的な意味での意匠表現は、建物の部分要素における細部の様 式や空間の規範的な関係によって成立してきたが、近代主義以降の 建築において装飾の重要性が相対的に低下していくなかで、空間構 成においても規範を相対化するような新たな関係が模索されてきた。 その結果、室内空間の意匠表現は部分要素による細部の様式や空間 の規範的な関係によるものから、室を構成する要素の配列などといっ た要素どうし、空間どうしの自由な構成関係によるものにその重心 を移行してきたように見受けられる。特に現代の住宅作品において 室内空間は壁や床、天井による室の限定と、空や建築化された家具 などの建築要素の形状や配列の関係を調整することによって意匠的 な表現を成立させている。そこで本研究では現代住宅建築の室内空 間の意匠表現を成立させる室形状と室内要素の配列の関係について
検討し、その関係による構成に類型的なあり方を見いだすことから、 現代建築の意匠表現の背景を成すパタン化された空間表現の形式を 明らかにする。本研究は、これらの類型的な構成形式の社会的な意 味や形の美醜あるいは外在的な事象との関係を問題にするのではな く、建物自体を成立させる構成形式による表現を問題にするもので ある。

\section{2 研究の方法と目的}

本研究では、現代日本の住宅作品の主室を対象に洋2)、室の形状と 室に配された要素の種類や配列を捉え、その関係を検討している。 室の形状とは、壁や床、天井によって限定された室の輪郭形状であり、 こういった部位 ${ }^{(i 3)}$ ごとの形状や天井高、全面開口の有無などによっ て性格づけられる。一方、そうした輪郭による室に配される密や建 築化された家具などの要素については、その種類を開口要素、面内 要素、立体要素といった形状による 3 種類から捉え、その室内にお ける配列を天井まわり、床まわりといった室の高さ方向についての 位置関係から検討する。例えば図 1 に示寸資料 No68 (日本橋の家) の主室の天井高は $6 \mathrm{~m}$ と一般的な住宅の室の天井高の 2 倍以上の高さ であるが、その室内は高さ方向を二分するように配された構造部材 と全面開口といった少ない要素によって秩序づけられている。また 図 1 資料 No55 (PLATFORM) の主室では、うねる天井の稜線に沿うよう に空やトラス、建築化された棚やテーブル、ベンチが配されており、
* 東京工業大学大学院 大学院生 $\cdot$ 修士 (工学)

** 東京工業大学大学院 名誉教授. 工博
Graduate Student, Graduate School, Tokyo Institute of Technology, M. Eng Prof. Emeritus, Graduate School, Tokyo Institute of Technology, Dr. Eng. 
さまざまな要素を覆いによって䌅めている。これらの例が示すよう に室の形状や、空や構造部材、棚などといった要素の配列次第で、 主室内部において様々な表現が成立し得ることが予想される。これ らのことから現代日本の住宅作品の主室に注目し、その形状と内部 空間での要素の配列について検討寸ることは、建築の意匠表現を捉 える上で重要であると考えられる。こうした認識をふまえ、本研究 では、現代日本の住宅作品の主室を対象とし、室を構成する部位の 形状と要素の配列といった構成的な水準から検討し、作品間に共通 寸る形式的なあり方を明らかにすることから、建築的要素の構成に よる意匠表現の一端を明らかにすることを目的とする注4。

\section{3 既往研究と本研究の意義}

住宅の内部空間の意匠表現について扱った既往の研究は数多くあ り、明治期には室の用途やそれに応じた部材や素材、装飾等に関し て具体的に論じるものがみられる ${ }^{1}$ 。

その後、装飾の重要性が相対的に低下寸るとともに、住宅の内部 空間についてはその構成を扱う研究が行われている。これには筆者 らによるもの ${ }^{2)}$ 以外には、分析対象を特定の建築家の住宅作品や、 特定の地域の伝統的な住宅に限定したもの ${ }^{3}$ や、平面や立面におけ る幾何学的な比例関係を問題にしたもの ${ }^{4)}$ 等があり、いずれも建築 の内部空間や外形をいくつかの単純なヴォリュームや幾何学の組み 合わせとして捉え、それらの関係を分析するものである。特に住宅 の主室を扱ったものには、主室を中心とした建築の内外の相関を論 じるもの ${ }^{5)}$ など、内一外といった空間の二元論を前提に内部空間を 端的に捉えるものとして主室を位置づけたものがみられる。

また、起居様式や生活形態についてのアンケートや実態調査によ り、室内空間の生活上のあり方を社会的、文化的背景、あるいは使 用の側面と重祆合わせて論じたもの ${ }^{6}$ もられる。

これらに対して本研究は、住宅の室内の意匠表現についてその内 的な空間構成から検討するものであり、床や壁、天井といった基本 的な構成材とともに開口や建築化された家具といった具体的に室内 空間を構成する部位どうしの関係を捉える事で、部位によって具体 的に構成される空間における意匠表現の形式的なあり方を明らかに しようとするものである。

このように建築家の表現の中心となる場として住宅の主室を扱

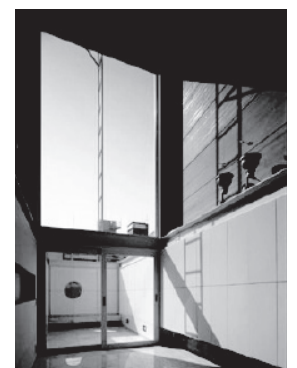

No68 日本橋の家/岸和郎

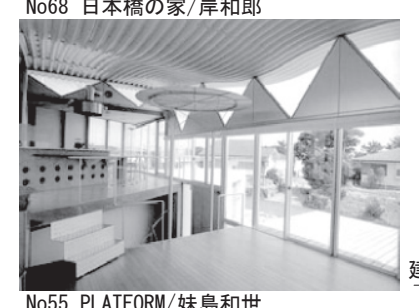

PLATFORM/妹島和世

図1 住宅の室形状と要素の配列
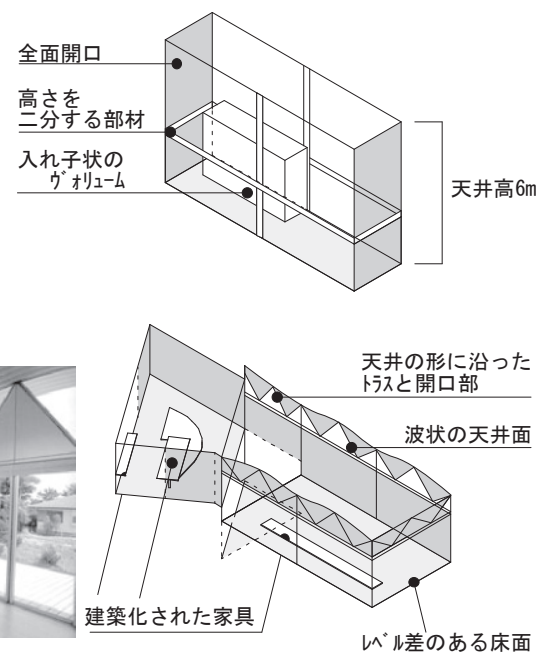

レ゙ル差のある床面
い、具体的に室内空間を構成する部位どうしの関係を意匠表現とし て捉えるという本研究で提示される視点はこれまでの学術的な研究 にはみられない。このことから、本研究は住宅の設計に際しての有 効な指針となるとともに、建築の構成研究に対する新たな展開を示 すものと思われる。

\section{2. 壁、床、天井による室の形状}

\section{2-1. 壁、床、天井の形状}

室は壁や床、天井といった部位によって三次元的に限定されたも のであることから、それら各部位の形状について検討することから 室の輪郭を大枠捉えることができる。本章では各部位の形状につい て検討し、それらの関係から室の形状による表現を明らかにする。

分析例（図 2 ）は台形の四隅がカーブした不整形な平面形状で水 平天井の室であり、1．5 層分の天井高をもつ。このように室の輪 郭は室の平面形状と、天井の勾配や床の段差などによって特徵づけ られる断面形状によって性格づけられている。こういった室の輪郭 をな寸部位の形状について主室の展開図を作成し検討した。

まず全資料についてその平面形状をみると、約 7 割 (83/123) が 長方形や正方形等の矩形平面であったことから、L字形や円形など 矩形ではないものを変形とし、矩形、変形の二種類から捉えた (表 1 )。

次に室の断面形状について、天井の形状と床面の段差の有無か ら検討した（表 2 )。このとき天井形状については勾配天井やドー ム形の天井等といった水平天井に対する変形の有無から検討した。 その結果、断面形状に変化をもつもの $(68 / 123)$ と、もたないもの (55/123) が約半数ずつみられ、断面形状に変化をもつものの多く は天井形状の変化によるもの (42/68) であった。また断面形状が一 定のものには天井高が 1 層分のものと 1.5 層分以上のものがほぼ 同程度みられた。

こうした室の上方を限定する天井面と、下方を限定する床面をつ なぐように垂直面の限定が加わることで室の輪郭が形作られる。こ の垂直面については、室の平面方向を限定する壁面と、壁面の大部 分を開口とすることで完全に限定せずに視線を外部と連続させる開 口面非)という 2 種類から捉えたところ (表 3 )、全資料の約 4 割が 開口面をもつもの (48/123) であった。

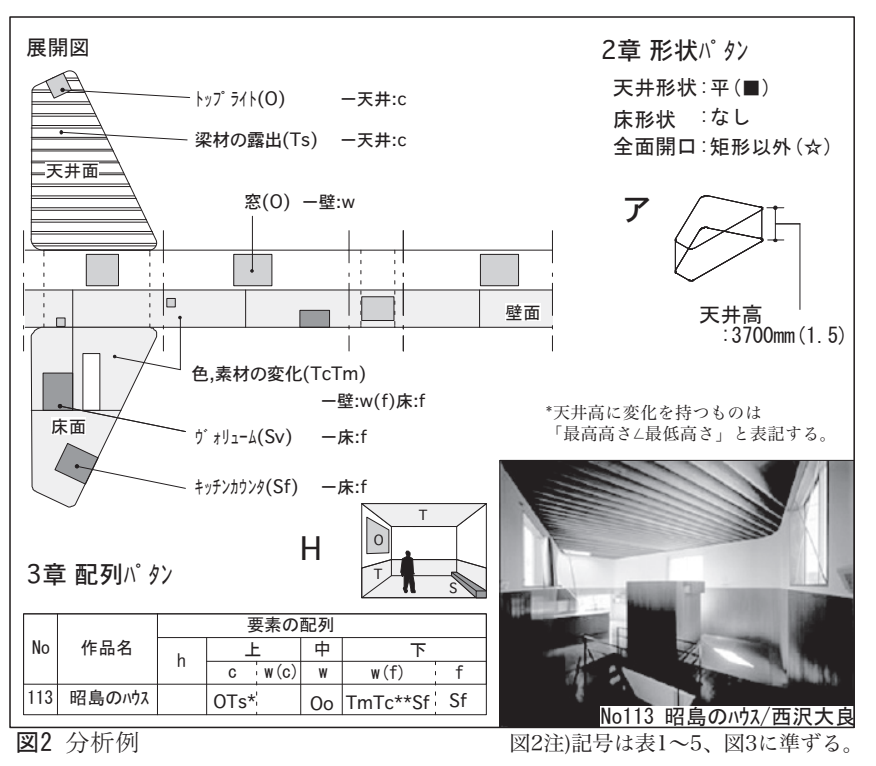




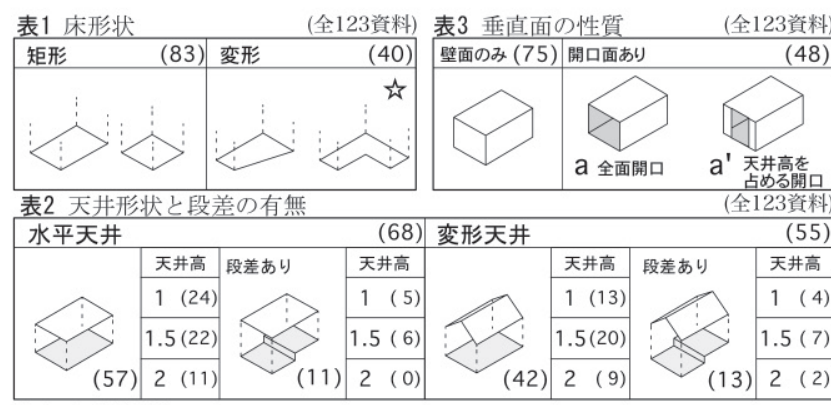

\section{表4 室形状パタン}

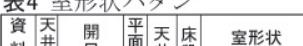

料型面面吞底室形状

\begin{tabular}{r|r|r} 
No & 状 \\
\hline 38 & 平 \\
\hline &
\end{tabular}

38
45 平
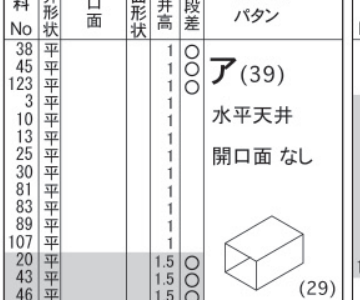

436 平

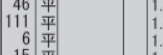

矩形平面
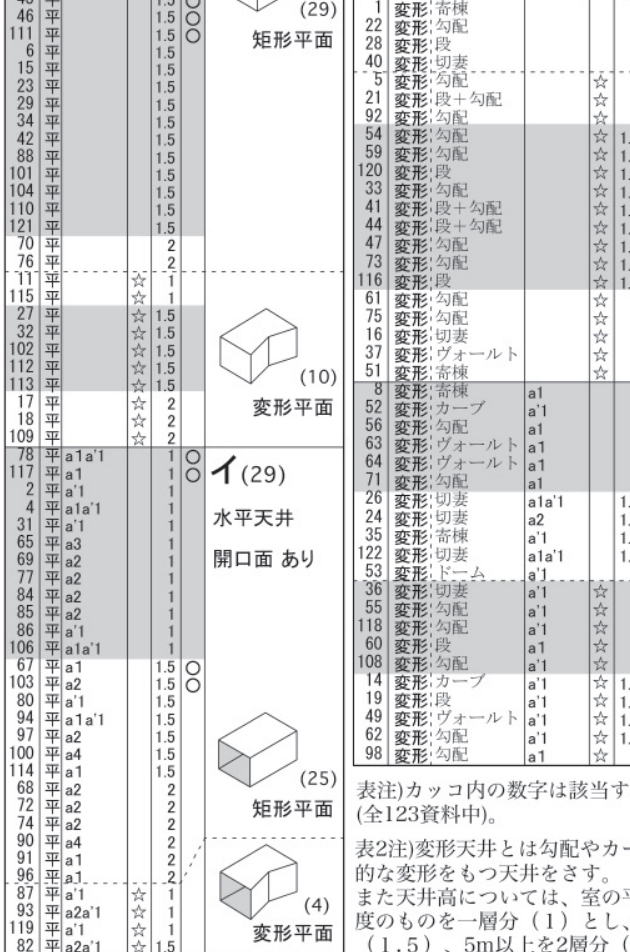

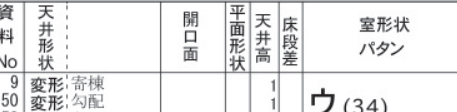

(6)

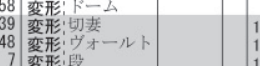

変形天井
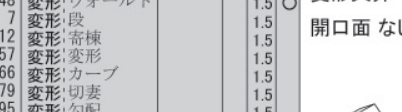

79
95
99 変形:

变形: : 青楝

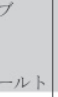

(1)

開口面なし
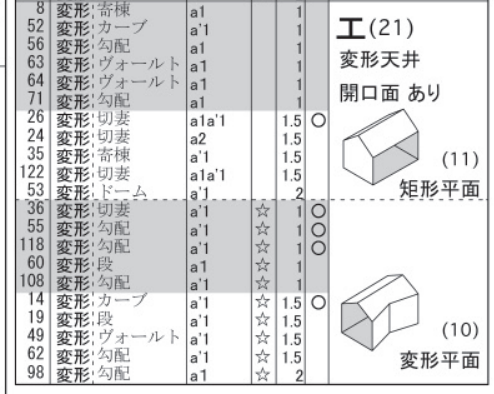

表注)カッコ内の数字は該当する資料数を示す (全123資料中)。

表2注)変形天井とは勾配やカーブ、段差などの断面 的な変形をもつ天井をさす。

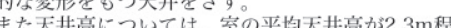
形平面 度のものを一層分 (1) とし、3.6m程度を 1.5 層分 82 平 $12 a^{\prime} 11$ 表 5 室内要素の種類

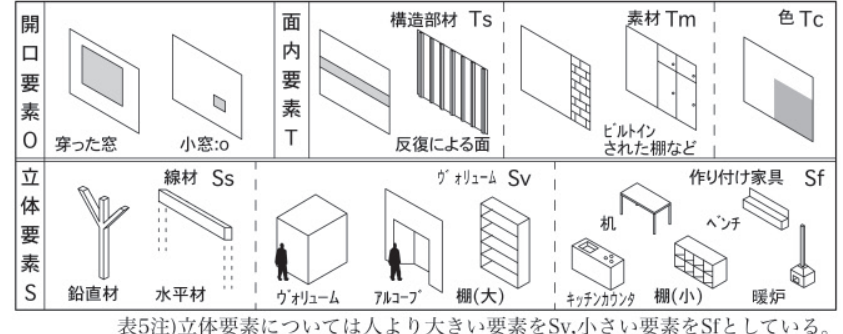

表5注)立体要素については人より大きい要素を $\mathrm{Sv}$,小さい要素をSfとしている。

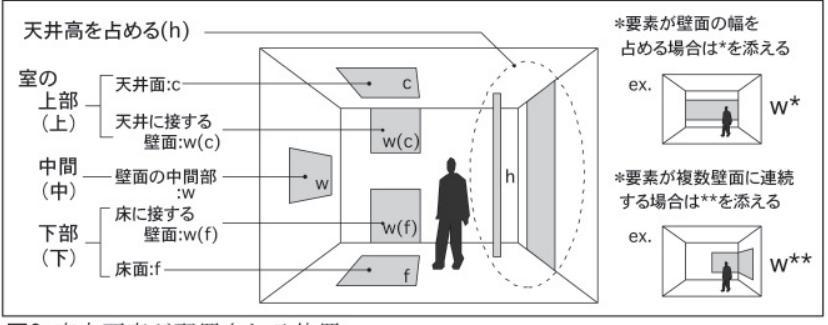

図3 室内要素が配置される位置

\section{2-2. 室の形状パタン}

室の形状は天井による高さ方向の限定と壁面による水平方向の限 定の形式の組み合わせによって特徵づけられると考えられる。そこ で、天井形状と垂直面の性質の組み合わせから室形状パタンを導き、 さらに床の段差の有無や天井高、平面形状をそれらの属性として重 ねて検討した（表 4 ）。

パタンアは水平天井で垂直面が壁面のみによるもので、床形状が 矩形である直方体の室が 7 割を占めた。パタンイは水平天井で垂直 面に開口面をもつものであり、大半が矩形平面のものであった。ま た半数以上が開口面を 2 面以上もつもので、 4 面が開口面による特 徵的なものもみられた。パタンウは変形天井で垂直面が壁面のみの もので、矩形平面のものと変形平面のものが半数ずつみられた。傾 向として、矩形平面のものには単純な勾配天井のものが、変形平面 のものには勾配やカーブの組み合わせによる複雑な天井形状のもの が多くみられた。パタンエは変形天井で開口面をもつもので、矩形 平面のものと変形平面のものが半数ずつみられた。

また開口面をもたないパタンアとパタンウにあたる主室の多くは 天井高が 1 . 5 層分以上のものであり、これに対して開口面をもつ パタンイ、パタンエでは半数以上が 1 層分の天井高の室であるとい う傾向がみられた。

\section{3. 室を構成する要素の種類と配列}

住宅の室内は、前章で検討した壁や床、天井によって限定された室 の輪郭に対して空や架構、建築化された家具注6) といった様々な要 素が配されることで一体的な空間表現を成立させている。例えば立 体的な要素が全くない平滑な室や、全ての要素が高さを揃えて配さ れた室などにみられるように、これら要素の種類や配列によって特 徵的な室内空間の表現が成立していると考えられる。そこで本章で は、室を構成する要素の種類と配列に着目し、それらの構成関係を 検討することから要素の配列による室内空間の意匠表現の広がりを 明らかにする。

\section{3-1. 要素の種類}

分析例（図 2 ）では、壁の上部はプラスターボードを白く塗装し、 壁の下部から床にかけての腰壁ではラワンベニヤを濃い茶色に着色 している。また壁際にキッチンカウンタ、床の中央には入れ子状に トイレのヴォリュームが配されている。また壁には空が穿たれ、天 井面には木製の梁材が反復し、さらにトップライトが配されると いった要素の配列がみられる。こうしたさまざまな要素が壁や床、 天井といった室を構成する面上に配される事で室内空間の意匠表現 を成立させている。

そこでこうした様々な要素を、穿った空による開口要素注7)、色 や素材の切り替えといった面内の表現や架構の反復、ビルトイン家 具などの室の面を構成する要素である面内要素、構造部材や作り付 け家具、入れ子状のヴォリュームやアルコーブなどの室内に立体と して現れる要素である立体要素の 3 種類に整理した（表 5 )。この とき立体要素については柱や梁などにみられる線状の形状のもの

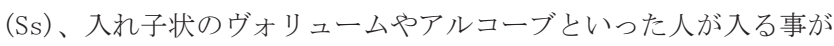
できる大きさのもの (Sv)、机やベンチ、キッチンカウンタ等の人 より小さなもの (Sf) の 3 種類を設定した。

各資料について室内を構成する要素の組み合わせを検討したとこ 
ろ、ほとんどの室が立体要素をもち (106/123)、室内に現れる要素を 開口要素のみ、あるいは面内要素の夕に限定し、室内の表面に凹凸 をもたないものは少数であり（開口要素のみ：8/123, 面内要素のみ 1/123）特殊な表現であるといえる。また資料の 4 割が開口要素、面 内要素、立体要素の全てをもつものであったことは、住宅の室内空 間が様々な種類や形状の部位の集合として成立していることを示す ものである。

\section{3-2. 要素が配される位置}

室を構成する要素は、例えば開口要素では天井に接するハイサイ ドライトや、床に接する掃き出し空というように、どの部位に接し て配されるかによって特徵的な表現を成立させている。そこで前節 で設定した要素の位置について、天井に接する室の上部（上）と床 に接する室の下部（下）、壁面の中間（中）、天井高を占めるような 配置（h）といった 4 種類から検討した（図 3 ）。また面の幅を占める ものや複数の面にまたがるといったような特徵的な配置の有無につ いても併せて整理したところ、全ての資料において床に接する部分 (下) に要素が配置されており、その中でも要素が室の上中下に配さ

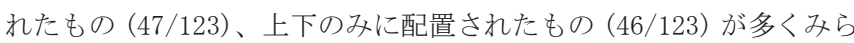
れ、室の下方のみに要素が限定されたもの $(13 / 123)$ は少数であった。

\section{3-3. 要素の配列パタン}

先に検討した要素の種類とその位置について併せて検討すること から、要素の配列パタン $(\mathrm{A} \sim \mathrm{J})$ を得た。

パタン A は開口要素のみのみによる室で、下部に配された掃出し 窓とともに中部もしくは上部にも開口要素をもつ。これは立体要素 がないため要素による凹凸のない室である。またパタン B、C は立 体要素のみのもので、このうち B は床のみに立体要素が配置された 室、C は独立柱などの天井高を占める立体要素の夕をもつ室である。 以上の単一の要素のみをもつ室に対して、パタン $\mathrm{D} 、 \mathrm{E}$ は開口要素と 立体要素をもつ室で、Dではそれらがともに床に接して配置されて

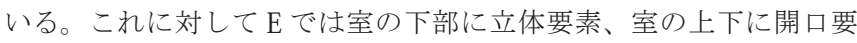
素が配されている。さらにパタン F は天井面から壁面にかけてを露 出された構造材などの面内要素が覆い、床に接して立体要素が配さ れたものである。一方パタン $G ＼mathrm{~ I ~ は 開 口 要 素 と 面 内 要 素 、 立 体 要 ~}$ 素をもつもので、いずれも室の下方のみに立体要素が配されている。 このうちG、I は開口要素が上下に配されたもので、このうちIには 天井高を占める面内要素が配されており、Gでは上中間部に面内要 素が配され、床周りと天井周りに要素が集中した室である。また H は壁の中間から上部に開口要素と面内要素があり、下部にいくつか の壁面をまたぐ面内要素と建築化された家具などの立体要素が配さ れており、室の中間部分に要素が多くみられるものである。一方パ タン Jは室の上下に開口要素と立体要素が配され、さらに室の上部 には露出し反復された梁材などの面内要素をもつもので、特に立体 要素が室内の上部、中間部、下部の全てに配されていることが特徴 的なパタンである。

これらのパタンを通じて、開口要素や立体要素は室の上中下で同 程度みられたが、面内要素のほとんどが室の上部と中間に配される といった傾向がみられた。また複数種類の要素をもつ室では、それ ぞれの要素が異なる位置に配されるものが多く、要素の種類を超え て位置を揃える部分をもつものもみられたが、全ての要素の配列を 揃えるものは少数であった。

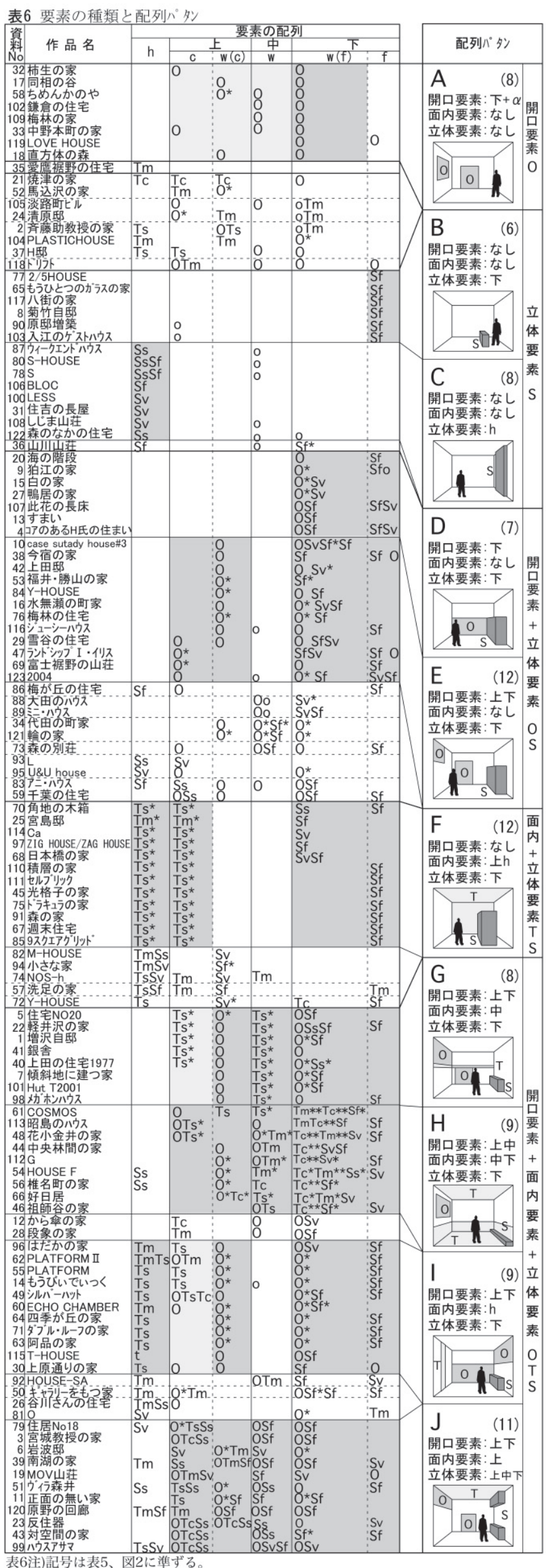


表7 室の形状と要素の配列による構成類型

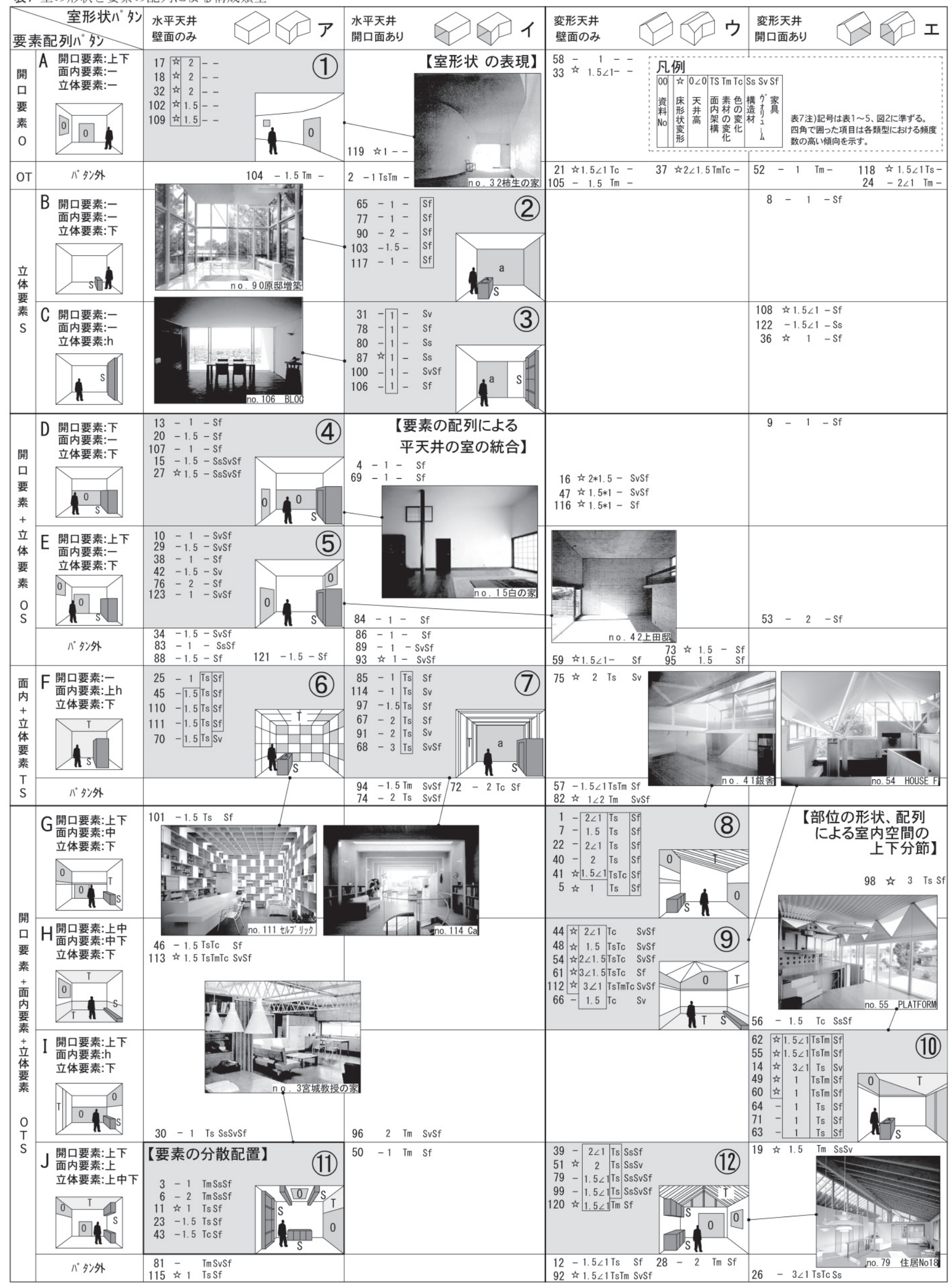




\section{4. 室形状と要素の配列による空間構成}

\section{4-1. 室形状と要素の配列による室内空間の構成類型}

住宅の室内空間は壁や床、天井といった部位による室の輪郭の形 状と、空や架構、建築化された家具といった要素の配列が重ね合わ されることで一体的に構成されたものとして捉えることができる。 そこで 2 章で得られた室の形状パタンと 3 章で得られた要素の配列 パタンを軸としたマトリクスを作成し、資料数の多いまとまりとし て 12 の類型をえた (表 7 )。

類型(1)は水平天井で室の下部と上部もしくは中間部の両方に空が 穿たれているもので、変形平面のものが多い。これは要素を開口要 素のみに限定し、室の凹凸をなくすことで室形状を表現するもので あるといえる。また立体要素の夕による類型(2)、(3)はいずれも開口 面をもつ水平天井の室で、このうち類型(2)は棚などの立体要素が壁 から離して配置されることで開放された開口面を表現したものであ る。一方類型(3)は棚や柱といった立体要素の高さを天井高に揃え、 室内に現れる部位や要素の高さを限定することによって室内に統一 性を与えているものであるといえる。類型(4)、(5)は水平天井の室で、 開口要素之立体要素のみをもつものである。いずれも立体要素が室 の下部に置かれているが、類型(4は開口要素も下部に揄えて配置さ れているのに対して、類型(5ではいくつかの穿たれた空が室の上下 にバランスをとるように配置されている。また面内要素と立体要素 をもつ類型(6)、(7)は水平天井から壁面にかけてを露出された構造部 材などの面内要素が覆い、床に立体要素の置かれた室である。この うち類型6は開口面をもたず、壁面を覆う架構に開口要素である小 窓や立体要素である棚などが組み込まれたもので、類型(7)は一方向 に開口面をもつフレーム状の架構によるものである。また類型(8) (12)空と面内要素、立体要素の全てをもつもので、このうち類型8 〜 (10、(12)はずれも勾配などを伴う変形天井の室である。類型(8)は 壁面の中間に幅いっぱいに配置された面内要素もち、室の下部に立 体要素が配されたもので、このなかには主室の上下で建具を介して 別の室に隣接するような吹き抜け状のものが多くみられた。また類 型9は室の下部に壁面をまたぐ色や素材の変化といった面内要素と 建築化された家具等の立体要素、室の上部に開口要素と面内要素が それぞれ配されたもので、要素による上下の分節が強い表現である。 さらに類型10は開口面をもつもので、室の上部にハイサイドライト、 室の下部に開口要素である掃出し空と建築化されたテーブル等の立 体要素が配され、別の壁面は素材の変化などといった面内要素が天 井高いっぱいに配されている。これら類型(9)、(10には変形平面のも のが多くみられ、室形状と要素の配列がともに室内を分節するよう な表現のものであった。また類型(12)は床周りや壁面の中間部分に立 体要素配され、面上に反復され露出した梁材といった面内要素をも つ変形天井がそれを覆うといった構成の室である。これらに対して 類型(11)水平天井で、上部に独立梁や吊り戸棚といった立体要素、 壁面に立体要素である棚や開口要素、さらに下部にもキッチンカウ ンタなどの立体要素というように室内に要素が分散して配置された もので、矩形平面の室が多くみられた。

各類型の年代傾向をみると、水平天井で全面開口をもつ類型であ る類型(2)、(3)、(7)はいずれも 90 年代後半から 2000 年代の作品 がほとんどであった。また変形天井をもち、さらに変形平面をもつ
ものの多い類型(9)、(10は 80 年代から 90 年代前半に多くみられた。 一方、水平天井の室に対して立体要素を床に空を上下に配した類型 (5)は各年代でまんべんなくみられるタイプであった。

\section{4-2. 室形状と要素の配列による空間構成の性格}

以上から、部位の形状と配列による住宅の主室の空間構成につい て大きく 4 つの性格を位置づけることができる。マトリクスの左上 にあたる類型(1)～(3)は室内に現れる要素の種類を限定することで平 面形状や開口面、天井高といった室の形状を強調するような表現の ものである。これらの約 8 割は 90 年代以降の作品であった。

また類型(4)は空と立体要素が配列によって統合されたもの、類型 (5)〜7)は空もしくは面内要素の配列が室内を秩序づけているもので、 これらはともに室の輪郭に対する操作を限定し要素の配列によって 水平天井の室を統合する表現といえる。

一方マトリクス右下の類型 8)～(10、112は変形を伴う天井による室 の上部と下部の差異を要素の配列が強調するもので、室の形状と要 素の配列がともに室内空間を上下に分節するような表現である。こ れらは、80 年代から 90 年代前半の作品に多くみられた。

以上のように室の形状や要素の配列、それら相互の関係によって 室内空間に主調をなす表現をつくるものと対照的に、類型11は水平 天井で室の全体に空や家具などといった要素が分散配置されたもの で、表現の中心となるような室形状や特定の要素の配列をもたない もので、建築家の表現として特異なあり方であるといえる。

\section{5. 結}

住宅の室内空間を壁や床、天井による室の形状と空や架構、建築 化された家具といった要素の種類や配列から捉え、それらを併せて 検討することから 12 の構成類型を導いた。これらの類型どうしの 関係から、室内を構成する要素を限定することによる「室形状の表現」 （ (1)～(3) )、「要素の配列による水平天井の室の統合」（ (4)～(7) )、「部 位の形状、配列による室内空間の上下分節」（ 8)～(10、 (12) )、室に主 調をな寸部位や配列をつくらない「要素の分散配置」( (11) ) といった 室形状と要素の配列の関係による大きく 4 つのあり方を明らかにし た。さらに室形状の強調という表現形式は 90 年代以降に、部位の 形状、配列による室内空間の上下分節は 80 年代から 90 年代前半 に多くみられるという年代的傾向を示した。

以上、ここでの分析を通して得られた結果は、室の輪郭形状と室 内を構成する要素といった建築の部位が互いに関係づけられながら 成立する意匠表現の枠組みを相対化するものであり、部分の関係に よる空間表現の新たなありかたを創作する上での一助になりうるも のと考える。

\section{参考文献}

1）保岡勝也：住家の室内装飾に就て（一)，建築雑誌 18 pp. $277 \sim 2841904$ ほか 11 編

2）塚本由晴、坂本一成：現代日本の住宅作品における空間の分節と接続 一住宅建築の構成形式に関する研究-，日本建築学会計画系論文集 N0.465 pp. 85 1994. 11

・塚本由晴、坂本一成 : 現代日本の住宅作品における空間の分割 一住宅建築 の構成形式に関する研究- , 日本建築学会計画系論文集 N0. 478 pp. 99 106 1995.12

3）那須聖、村田涼、八木幸二：内部空間との関係にみる近代住宅の外部空間 
の構成に関する研究 - 南カリフォルニアにおける R. M. シンドラーとR. J. ， イトラの住宅の比較を通して一, 日本建築学会計画系論文集 N0.528 pp. 133 〜 1392000.2

・末包伸吾 : ルドルフ・シンドラーの住宅建築における空間構成材とモデュー ルによる空間構成法, 日本建築学会計画系論文集 N0. 494 pp. $261 \sim 267$ 1997. 4 ほか

4）加藤道夫、広部達也：ル・コルビュジェの形態的解釈 一第 I I 部 形式的体 系によるル・コルビュジェ解釈 - , 日本建築学会論文報告集 N0. 342 pp. 132 〜 145 1984.8 ほか

5）小川次郎、小野田環、坂本一成：外形ヴォリュームと室の配列による建築 の構成, 一現代日本に住宅作品における内外の関係による構成形式 -, 日本 建築学会計画系論文集 N0.537 pp. 117～123 2000.11

・岡村航太, 小川次郎, 坂本一成: 外部空間の配列と接続からみた都市型住宅 作品の構成, 一現代日本の住宅作品における内外の関係による構成形式 (2)日本建築学会計画系論文集 N0.552 pp. $141 \sim 1462002.2$

6) 沢田知子：イス座家具導入過程からみた起居様式の指向性 一現代住宅にお ける起居様式の変遷過程に関する研究 (その 1 ) -, 日本建築学会計画系論 文集 第 438 号、pp33〜 42, 1992.8 ほか

- 宇野浩三, 足達富士夫, 眞嶋二郎: 公室空間の構成と生活形態 - 北海道の 戸建住宅における公室空間に関する研究 (1) - , 日本建築学会計画系論文集 N0. 401 pp. 57 ～ 63 1989. 7 ほか

\section{注}

注 1) 本研究では各住宅作品を構成する室のうち、全体の中で相対的に他より 大きい室を「主室」としている。

また建築設計資料集成 総合編（日本建築学会編、丸善、2001）には「比較 的規模の小さい建築では、内部空間における最大の室は全体構成に大きな影 響を与える。室建築の内部空間はこうした最大の、主となる室（主室）と、 それ以外の通常の大きさの室（室）からなる空間単位が集合する事で構成さ れる。」(一部抜粋) とあり、本研究で扱う「主室」はこれを前提としている。 注 2)「新建築」及び「新建築住宅特集」誌（1985 年創刊、86 年より月刊化） における $1951 〜 2001$ 年の年末アンケート、及び $2002 \sim 2006$ 年の月評にお
いて評価されたもののうち図面不備のものを除いた 123 作品の主室を資料と している。

なお、資料番号はそれぞれ以下の各年代に対応している。

No. 1-8：1950 年代、No. 9-15: 1960 年代、No. 16-41: 1970 年代、

No. 42-59: 1980 年代、No. 60-92 : 1990 年代、No. 93-123:2000 年代

注 3)「部位」とは 建築用語辞典(第 2 版、日本建築学会編、岩波書店) によると、 「屋根、床、壁、天井など、建築物を構成する面状の要素、又はその位置。」 とある。本論文ではこれに習い、空間を限定する面である壁や床、天井を部 位とし、穿たれた空や扉、構造部材、建築化された家具等の室内に作り付け られた部分を室内要素としている。

注 4）本研究の分析・検討内容は、筆者らによって一部報告されたものを再検 討し、加筆・修正した上でまとめたものである。

拙稿 根本理恵、坂本一成、中井邦夫、安森亮雄、足立真、久野靖広ほか

「主室における部位の形状と配列 : 住宅の内部空間の構成に関寸る研究 (1)」 日本建築学会大会学術講演梗概集 (九州) pp. 797-798 2007.8

「部位の形状と配列による空間構成:住宅の内部空間の構成に関寸る研究 (2)」 日本建築学会大会学術講演梗概集 (九州) pp. 799-800 2007.8

注 5)「開口」とは建築用語辞典（第 2 版、日本建築学会編、岩波書店）によると、 「建物の屋根、壁、床、天井の一部が解放された部分。採光、通風、換気、 人の出入りなどの目的で設けた空や出入り口など。とある。本論文では、 床から天井までの高さを占め、さらに壁の面積の半分以上を占める開口を壁 面の欠如した部分と捉え開口面としている。

注 6)「家具」とは 大辞林（第 2 版、三省堂）によると「家の中に据えて用い る道具。机、椅子、たんすなど。」とあるが、本論文では設計者の意図が反 映されたものとして、可動式のテーブルや椅子等を除き、室内に固定され建 築化された家具のみを扱う。

注 7）穿った空、水平連想などの部分的な開口を上記注 5 の「開口面」に対し て「開口要素」としている。

なお、換気空等の小空については表中。(小文字) で示すがパタンをとりだ 寸際には開口要素としての重み付けはしていない。

（2010年 3 月 8 日原稿受理，2010年 5 月17日採用決定） 